\title{
KARAKTERISTIK KARET LEMBARAN DENGAN BAHAN PENGISI ARANG AKTIF BAMBU
}

\author{
The Characteristics of Rubber Sheet with Activated Bamboo Charcoal Filler
}

\author{
Popy Marlina ${ }^{1^{*}}$, Asma Assa ${ }^{2}$ dan Hari Adi Prasetya ${ }^{1}$ \\ ${ }^{1}$ Baristand Industri Palembang \\ Jl. Perindustrian II No.9. Sukarami Palembang \\ ${ }^{2}$ Balai Besar Industri Hasil Perkebunan Makassar \\ Jl. Prof. Dr. Abdurahman Basalamah No.28 Makassar \\ ${ }^{1 *}$ e-mail: popymarlina16@gmail.com
}

\begin{abstract}
The activated bamboo charcoal as an alternative to improve the hardness and increase rubber volume that leads to better rubber sheet quality. The study aims to determine the characteristics of rubber sheet with raw latex composite materials and activated bamboo charcoal. The amount of activated bamboo charcoal in rubber sheet formulation was varied in different mass, which was 25, 30, 35, 40, 45, and 50 grams. Each treatment was replicated three times. The parameters were ash content, initial plasticity (Po), Plasticity Resistance Index $(P R I)$ and Mooney viscosity. The results showed that the variations of treatment in the amount of activated bamboo charcoal affected ash content, initial plasticity (Po), Plasticity Resistance Index (PRI) and Mooney viscosity. The characteristics of rubber sheet met the quality of Standard Indonesian Rubber (SIR) requirements according to SNI 06-1903-2000 with ash content characteristics for all treatments, Po and PRI, the treatments of F3 (raw latex of $945 \mathrm{~g}$ and activated bamboo charcoal of $35 \mathrm{~g}$ ) to F6 (raw latex of $945 \mathrm{~g}$ and activated bamboo charcoal of $50 \mathrm{~g}$ ). The mooney viscosity of rubber sheet for all treatments met the quality standard of commercial SIR, minimum 40.
\end{abstract}

Keywords: activated bamboo charcoal, characteristic, rubber sheet

\begin{abstract}
Abstrak: Bahan pengisi arang aktif bambu digunakan sebagai alternatif untuk memperbaiki kekerasan dan memperbesar volume karet sehingga mutu karet lembaran menjadi lebih baik. Penelitian ini menggunakan arang aktif bambu yang dapat berfungsi sebagai filler aktif untuk meningkatkan karakteristik karet lembaran. Jumlah arang aktif bambu pada formulasi karet lembaran divariasikan menjadi 6, yaitu 25, 30, 35, 40, 45, 50 gram. Setiap perlakuan diulang sebanyak 3 (tiga) kali. Parameter yang diamati meliputi kadar abu, plastisitas awal (Po), Plasticity Resistance Index (PRI), dan viskositas Mooney. Hasil penelitian menunjukkan bahwa perlakuan variasi jumlah arang aktif bambu berpengaruh terhadap kadar abu, plastisitas awal (Po), Plasticity Resistance Index (PRI), dan viskositas Mooney. Karakteristik karet lembaran memenuhi syarat mutu Standard Indonesian Rubber (SIR) sesuai SNI 06-1903-2000 dengan karakteristik kadar abu untuk semua perlakuan, Po dan PRI, perlakuan F3 (lateks pekat $945 \mathrm{~g}$ dan arang aktif bambu $35 \mathrm{~g}$ ) hingga F6 (lateks pekat $945 \mathrm{~g}$ dan arang aktif bambu $50 \mathrm{~g}$ ). Viskositas Mooney karet lembaran untuk semua perlakuan memenuhi standar mutu karet SIR komersial, minimal 40.
\end{abstract}

Kata Kunci: arang aktif bambu, karakteristik, karet lembaran

\section{PENDAHULUAN}

Lateks merupakan bahan baku karet alam yang diperoleh melalui penyadapan pohon karet (Hevea brasiliensis). Salah satu penggunaan bahan pada industri karet adalah karet alam. Keunggulan karet alam terutama terletak pada sifat elastis dan kemudahan pembentukannya. Kandungan karet alam antara lain garam organik, fosfolipid, hidrokarbon, karbohidrat, glikolipid, protein, mineral enzim dan berbagai bahan lain (Muis, 2010).

Lateks yang tidak mendapatkan penanganan dengan tepat, mutunya akan menurun selama penyimpanan. Permasalahan pada bokar yang dialami petani karet adalah cepat menggumpalnya lateks setelah disadap. Hal ini sangat mempengaruhi 
mutu bokar yang dihasilkan karena memiliki bau busuk yang disebabkan oleh bakteri yang merusak antioksidan alami pada bokar dan memicu penurunan nilai plastisitas awal (Po) dan Plasticity Retention Indeks (PRI) pada produk olahan karet selanjutnya. Lateks akan segera menggumpal dalam beberapa jam bila tidak segera dilakukan pengawetan. Penggumpalan lateks secara alami ini dapat dihindari dengan cara pengawetan. Lateks terlebih dahulu dipekatkan sebelum digunakan dalam pembuatan barang jadi karet. Salah satunya dengan cara sentrifugasi (pemusingan) yang bertujuan untuk memisahkan antara dua fraksi, yaitu fase berat berupa lateks skim dan fase ringan berupa lateks pekat. Lateks yang akan dibuat menjadi barang karet terlebih dahulu digumpalkan. Bahan koagulan bokar yang digunakan untuk menggumpalkan lateks adalah asam semut dan asap cair (deorub) yang berfungsi sebagai pemantap dan membentuk koagulum.

Karet alam memiliki kelemahan karakteristik, terutama viskositas Mooney yang selalu berubah-ubah. Faktor- faktor yang mempengaruhi sifat fisik dan dinamis produk karet, kemudahan dalam proses pembuatan dan kualitas produk karet, yaitu karakteristik karet alam seperti plastisitas awal (Po), Plasticity Resistance Index (PRI), viskositas Mooney, kadar kotoran dan kadar abu (Marlina dan Prasetya, 2017). Menurut Vachlepi dan Suwardin (2015), selama proses penyimpanan (storage hardening) karet alam akan terjadi pengerasan, hal ini karena terjadinya reaksi ikatan silang. Terjadinya reaksi ikatan silang dapat diatasi dengan penggunaan bahan pemantap.

Penelitian peningkatan karakteristik mutu karet alam telah banyak dilakukan, diantaranya Vachlepi dan Suwardin (2015) yang menggunakan zat pemantap hidrazin untuk meningkatkan mutu SIR 20; Aguele et al., (2015) dengan penelitian peningkatan mutu karet alam menggunakan metode pengeringan; dan Sirait (2011) yang melakukan penelitian pemanfaatan sari jeruk nipis dan asam format digunakan sebagai bahan penggumpal untuk meningkatkan mutu vulkanisat karet. Penelitian arang aktif bambu sebagai bahan pengisi karet shock dumper (Marlina et al., 2018), menghasilkan karakteristik shock dumper yang tahan terhadap panas.

Menurut (Krisdianto et al., 2000, Daud dan Ali, 2004), kandungan selulosa tanaman bambu 42,40$53,60 \%$, merupakan komponen arang aktif. Ketersediaan tanaman bambu banyak dan murah sehingga dapat dijadikan sebagai arang aktif. Menurut (Roslan et al., 2015), sifat mekanik serat bambu, diantaranya memiliki sifat mekanik yang baik, kepadatan rendah dan kekuatan tinggi. Rijali et al., 2015, menyatakan bahwa karbonisasi merupakan proses untuk memperoleh arang aktif bambu dan telah mengalami reaksi dengan bahan kimia untuk menghasilkan karbon bebas dan karbon berpori yang berdaya serap tinggi. Untuk memperoleh permukaan yang lebih halus maka dilakukan aktivasi arang bambu. Struktur pori internal berhubungan dengan luas permukaan arang aktif, sehingga arang aktif mempunyai sifat sebagai absorber yang lebih baik.

Pada penelitian ini akan digunakan arang aktif bambu yang dapat berfungsi sebagai filler aktif untuk meningkatkan karakteristik karet lembaran, dengan tujuan memperbesar volume dan dapat memperbaiki kekerasan karetnya. Penggunaan arang aktif bambu sebagai bahan pengisi dan pemantap dalam proses pengolahan lateks, akan meningkatkan penggunaan karet alam, karakteristik dan stabilitas karet, terutama karet lembaran.

\section{METODOLOGI}

\section{Bahan dan Alat}

Penelitian ini menggunakan bahan- bahan, meliputi lateks pekat kadar karet kering (KKK) 60\%, asam formiat (asam semut) dan arang aktif 
bambu 400 mesh.

Peralatan yang digunakan terdiri dari mesin mangel karet, open mill, neraca analitis, stopwatch, oven, mixer agitator, Mooney Viscometer dan peralatan gelas.

Tabel 1. Perbandingan Penggunaan Arang Aktif Bambu dan Lateks

\begin{tabular}{cccccccc}
\hline No & \multicolumn{1}{c}{ Bahan } & F1 & F2 & F3 & F4 & F5 & F6 \\
\hline 1. & Lateks pekat $(\mathrm{g})$ & 945 & 945 & 945 & 945 & 945 & 945 \\
2. & Arang aktif bambu $(\mathrm{g})$ & 25 & 30 & 35 & 40 & 45 & 50 \\
\hline
\end{tabular}

\section{Metode Penelitian}

\section{Rancangan Penelitian}

Rancangan dengan faktor perlakuan perbandingan modifikasi lateks dan arang aktif bambu. Perbandingan penggunaan arang aktif bambu dengan lateks ditunjukkan pada Tabel 1.

\section{Prosedur Percobaan}

Pencampuran lateks pekat dengan arang aktif bambu sesuai formula dan diaduk, kemudian ditambahkan asam formiat sampai $\mathrm{pH}$ 4,5 sambil terus diaduk menggunakan mixer agitator. Setelah homogen dan membentuk koagulum, pengadukan dihentikan dan ditambahkan air sebanyak $250 \mathrm{ml}$ dan dilakukan pemeraman selama 24 jam.

Sampel karet yang telah dilakukan pemeraman, digiling menggunakan mesin mangel dan dikeringkan dalam oven, selama 3 jam, suhu $105^{\circ} \mathrm{C}$. Sampel karet yang telah dikeringkan digiling menggunakan open mill.

Hasil yang diperoleh akan mengacu spesifikasi mutu karer alam berdasarkan SNI 06-1903-2000 (Tabel 2).

Tabel 2. Spesifikasi Mutu Karet Alam Berdasarkan SNI 06-1903-2000 (BSN, 2000)

\begin{tabular}{clcc}
\hline \multirow{2}{*}{ No. } & \multirow{2}{*}{ Karakteristik } & \multicolumn{2}{c}{ Persyaratan } \\
\cline { 3 - 4 } & & SIR 10 & SIR 20 \\
\hline 1. & Kadar abu (\%) & Maks. 0,75 & Maks. 1 \\
2. & PRI & Min. 60 & Min. 50 \\
3. & Po & Min. 30 & Min.30 \\
4. & Viskositas Mooney & - & - \\
\hline
\end{tabular}

\section{Variabel yang Diamati}

Variabel penelitian ini meliputi 06-1903-2000. Tahapan penelitian plastisitas awal (Po), Plasticity yang dilakukan adalah seperti Gambar Resistance Index (PRI), viskositas 1.

Mooney (VM), dan kadar abu.

Pengujian dilakukan sesuai dengan SNI 


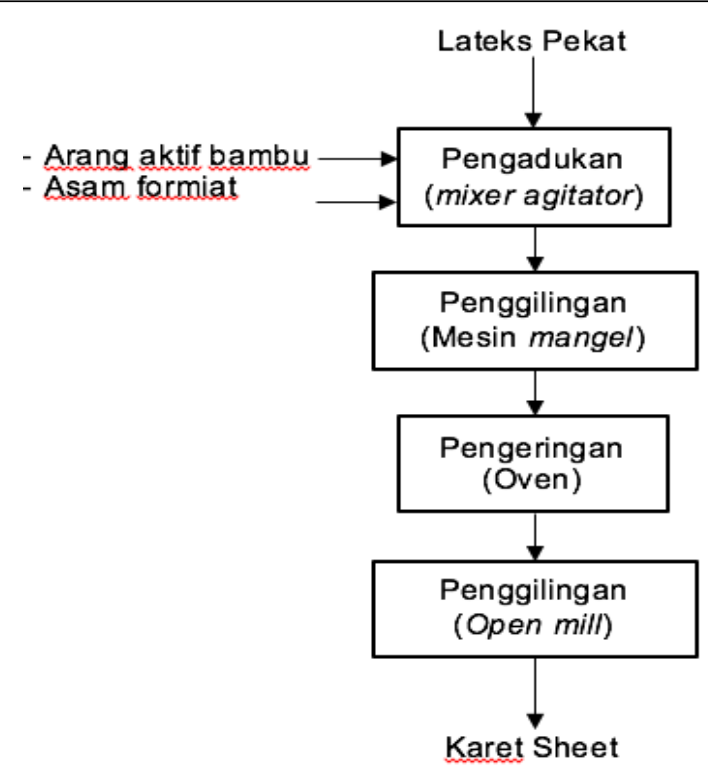

Gambar 1. Tahapan Pembuatan Karet Sheet dari Lateks Pekat

\section{HASIL DAN PEMBAHASAN}

\section{Kadar Abu}

Kadar

persentase kandungan bahan lain nonkaret terutama senyawa anorganik yang terdapat pada karet alam. Hasil pengujian kadar abu karet lembaran tertinggi diperoleh pada perlakuan F6 (berat arang aktif bambu 50 gram), yaitu $0,75 \%$ dan kadar abu karet lembaran terendah diperoleh pada perlakuan F3 (berat arang aktif bambu 35 gram), yaitu $0,58 \%$. Kadar abu karet lembaran hasil pengujian pada Gambar 2.

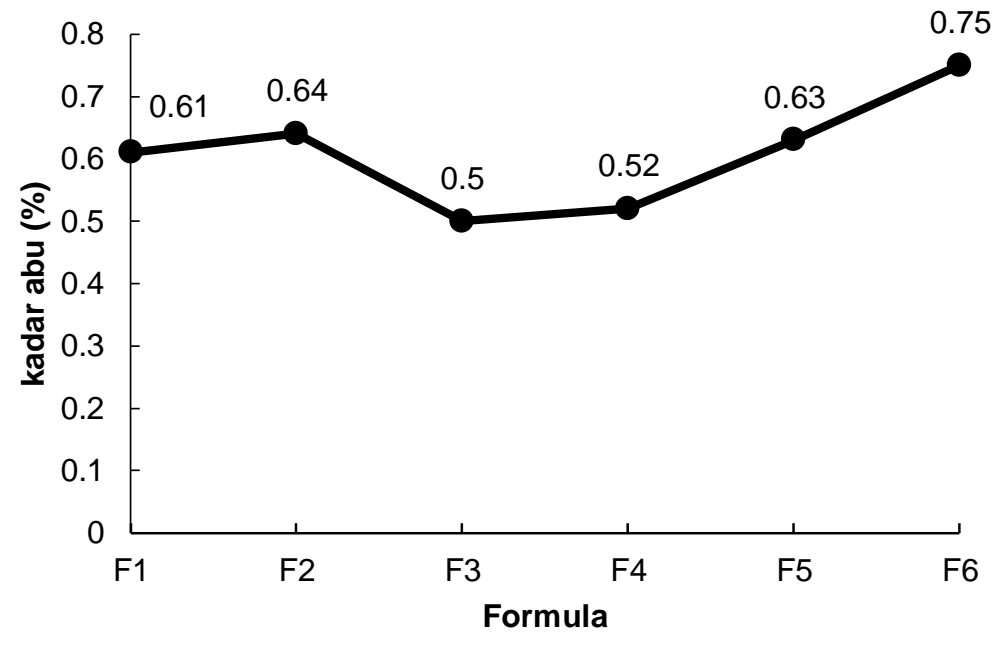

Gambar 2. Kadar Abu Karet Lembaran

Berdasarkan Gambar 2, semakin besar jumlah arang aktif yang ditambahkan dalam pengolahan karet lembaran, semakin besar kadar abu yang terkandung dalam karet. Arang aktif bambu dapat meningkatkan nilai kadar abu, meskipun peningkatan antar perlakuan tidak terlalu signifikan.

Penambahan bahan pengisi ke dalam karet merupakan faktor yang sangat mempengaruhi kadar abu koagulum lateks dalam pembuatan slab (Asni dan Novalinda, 2012). Arang aktif 
bambu terdiri dari atom karbon bebas yang porinya bersih dari senyawa lain, memiliki permukaan dan pusat aktif luas, serta kemampuan adsorbsinya meningkat (Cao et al., 2011). Hal ini menyebabkan pengotor yang terkandung dalam arang aktif relatif tidak ada sehingga hasil pengujian kadar abu karet lembaran yang ditambahkan bahan pengisi arang aktif bambu menghasilkan nilai yang rendah. Sesuai dengan pendapat George dan Jacob (2010), total konsentrasi senyawa atau ion anorganik di dalam lateks segar yang dihitung sebagai abu kurang lebih $0,50 \%$. Selain itu, bahan baku karet lembaran berupa lateks pekat masih mengandung beberapa kontaminan. Kadar abu berhubungan dengan kandungan mineral pada suatu bahan. Abu yang terkandung dalam karet mentah terdiri dari oksida logam, dan garam anorganik seperti karbonat, fosfat, sulfat, kalium, magnesium, kalsium, dan beberapa unsur lain (Handayani, 2014).

Kadar abu karet lembaran pada semua perlakuan (0,58-0,75\%) memenuhi persyaratan jenis mutu karet SIR 10 (Tabel 1) yang mensyaratkan kadar abu maksimal 0,75\%.

\section{Plastisitas}

Nilai plastisitas awal (Po) dan Plasticity Resistance Index (PRI) merupakan parameter dasar untuk menentukan mutu karet lembaran (Ahmadi et al., 2015). Plastisitas awal (Po) merupakan pengujian terhadap karet yang belum diusangkan yang menggambarkan kekuatan karet. Semakin tinggi nilai plastisitas awal maka semakin kecil energi yang diperlukan dalam proses pembuatan kompon karet (Sirait, 2011). Hasil pengujian diperoleh nilai Po terendah pada perlakuan $F 1$, yaitu 26 dan nilai tertinggi diperoleh pada perlakuan F5, yaitu 40. Hasil pengujian Po karet lembaran disajikan pada Gambar 3.

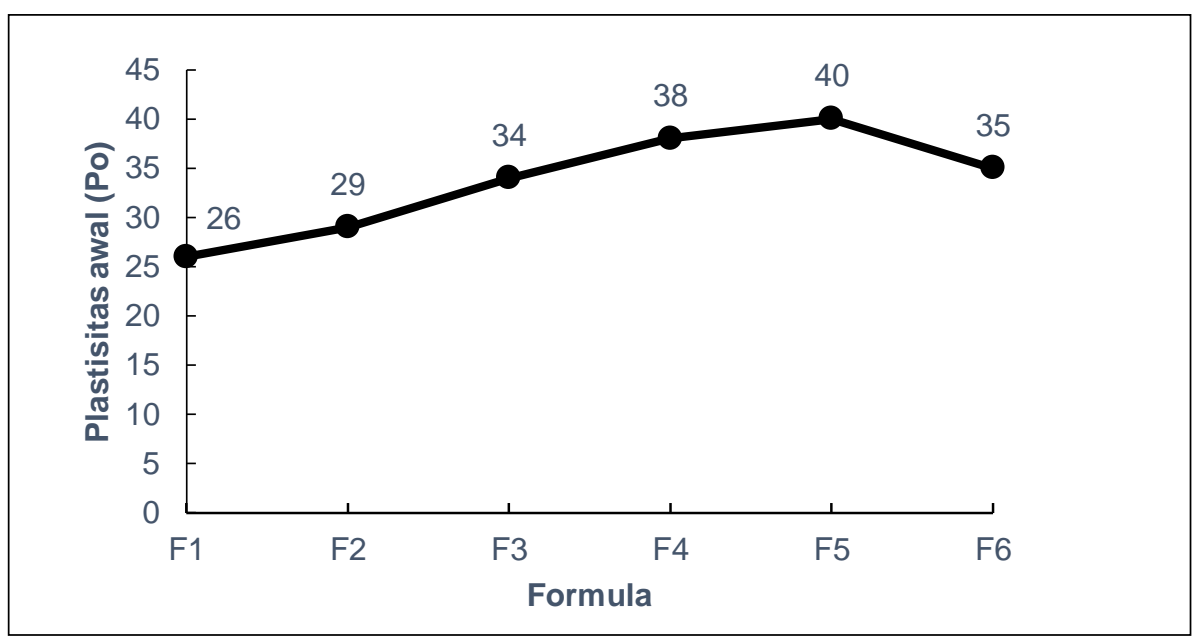

Gambar 3. Plastisitas Awal Karet Lembaran

Gambar 3 menunjukkan semakin besar jumlah arang aktif bambu yang ditambahkan, semakin besar nilai Po dan mencapai nilai tertinggi pada perlakuan F5. Peningkatan nilai Po menunjukkan proses maturasi lebih ke arah ikatan silang rantai karet yang panjang (Zhong et al., 2009). Rantai molekul karet alam yang tahan terhadap oksidasi memiliki plastisitas awal yang tinggi dan polanya sama seperti PRI, dimana gugus aktif hidroksil $(\mathrm{OH})$ yang terdapat pada permukaan arang aktif bambu akan berikatan dengan molekul karet menghasilkan karakteristik karet lembaran yang lebih baik.

Selain itu, klon karet yang terdiri dari mikrogel dan makrogel, mempengaruhi nilai Po (Refrizon, 2003). Storage hardening merupakan gel yang terbentuk secara spontan 
akibat adanya ikatan silang dalam karet mentah. Karet yang memiliki gugus aldehida abnormal yang menyebabkan ikatan silang tersebut terbentuk secara alami. Ikatan silang terbentuk saat lateks masih terdapat dalam pohon (intra particle crosslinks) yang disebut dengan mikrogel. Makrogel terbentuk dari ikatan silang dalam keseluruhan struktur karet selama pengeringan dan penyimpanan, antara gugus aldehida dan gugus aldehida yang terkondensasi (Vachlepi dan Suwardin, 2015).

Interaksi komposit karet lembaran dan arang aktif bambu menghasilkan perlakuan terbaik Po pada perlakuan F3 hingga F6 dengan nilai Po sebesar 34-40. Perlakuan tersebut dipilih berdasarkan nilai Po berdasarkan SNI SIR 06.1903-2000 mutu SIR 10 dan SIR 20 (Nilai Po minimal 30).

Ketahanan karet mentah terhadap degradasi oleh oksidasi pada suhu tinggi dapat diketahui melalui nilai PRI karet mentah. Tinggi rendahnya nilai PRI dipengaruhi oleh jenis bahan baku yang digunakan dan proses pengolahan karet. Semakin tinggi nilai PRI berarti ketahanan karet mentah terhadap degradasi akan semakin tinggi, yang berarti karet menjadi semakin keras. Lama penyimpanan mempengaruhi nilai PRI. Kondisi lingkungan (suhu, $\mathrm{pH}$, dan oksigen dalam udara) selama penyimpanan. Kondisi tersebut karena adanya perubahan keseimbangan antara senyawa antioksidan (protein, asam amino, tocotrieniols) dan pro-oksidan (asam lemak bebas tak jenuh dan ion logam bebas) dalam karet alam (Intapun et al., 2009). Hasil pengujian PRI karet lembaran dapat dilihat pada Gambar 4.

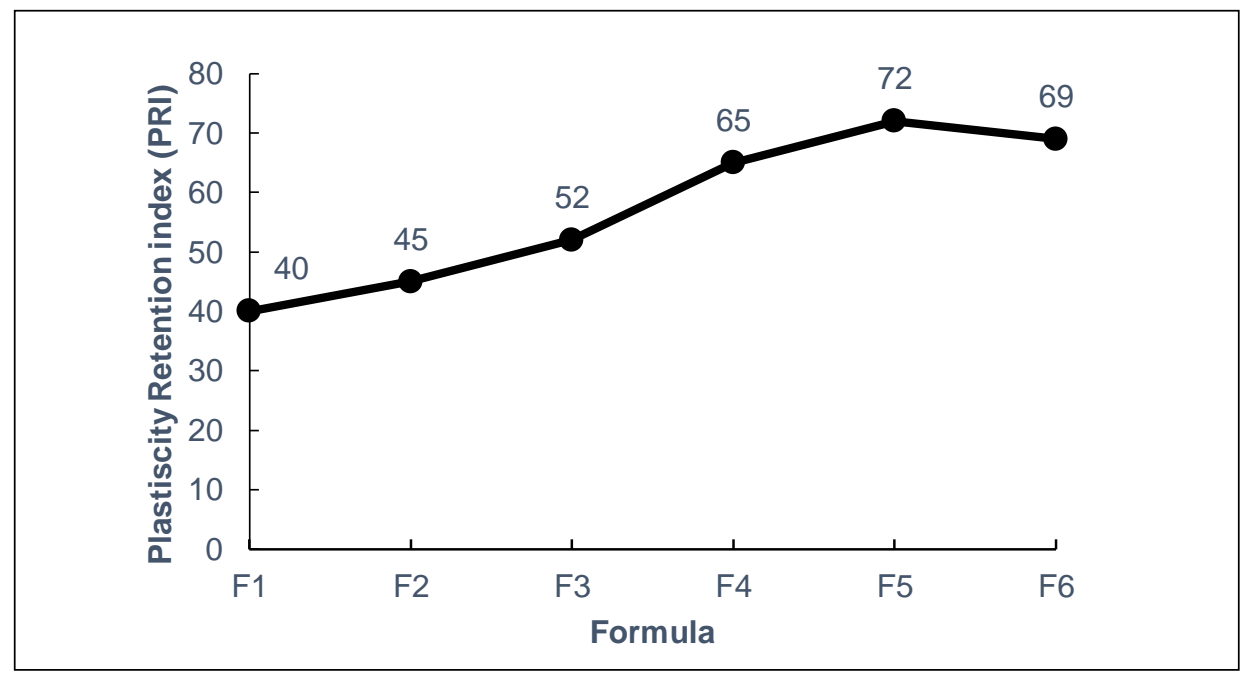

Gambar 4. Plastiscity Retention Index (PRI) Karet Lembaran

Berdasarkan Gambar 4, perlakuan F5 menunjukkan nilai PRI karet lembaran tertinggi, yaitu 72 dan nilai terendah diperoleh pada perlakuan F1, yaitu 40. Ketahanan karet lembaran terhadap degradasi oksidasi dan ozon, menunjukkan nilai PRI yang tinggi. Ini berarti bahwa bahan tersebut dapat mempertahankan sifat-sifat baiknya selama beberapa waktu sehingga meningkatkan kualitas untuk produk karet berikutnya (Aguele et al., 2015).
Arang aktif bambu mengandung gugus aktif hidroksil memberikan efek perlindungan antioksidan terhadap karet. Ikatan silang baru terbentuk karena adanya kemampuan gugus hidroksil $(\mathrm{OH})$ berinteraksi dengan molekul karet. Ikatan silang tersebut mempunyai ketahanan oksidasi yang lebih baik (Komethi et al., 2012).

Oksidasi karet alam dapat dicegah dengan adanya senyawa antioksidan. Ketahanan oksidasi karet alam pada suhu tinggi dapat diketahui 
melalui pengujian $\mathrm{PRI}$ karet alam. (Vachlepi dan Suwardin, 2015). Selain itu, PRI juga sebagai petunjuk atau deteksi awal untuk melihat kerusakan karet sperti lunak atau lengket, akibat cuaca atau kondisi lingkungan (Marlina dan Prasetya, 2017). Hasil analisis PRI terbaik diperoleh pada perlakuan F3 hingga F6, yaitu kisaran nilai sebesar 52 hingga 72 . Perlakuan tersebut memenuhi mutu SIR 10 dan SIR 20 yang dipersyaratkan SNI 06-1903-2000 (Tabel 2).

\section{Viskositas Mooney}

Pengujian viskositas Mooney merupakan salah satu prosedur paling umum yang dilakukan dalam industri karet (Malac, 2009). Viskositas Mooney terutama mengukur karakteristik pengolahan seperti rheology dari kompon karet (Eighwaikidhe et al., 2013). Viskositas Mooney menggambarkan panjang rantai molekul karet alam. Parameter mutu ini memegang peranan penting dalam proses pencampuran ketika pembuatan kompon, baik untuk tingkat dispersi bahan-bahan kimia kompon di dalam karet maupun energi yang diperlukan untuk penggilingan di mesin pencampur. Dengan demikian, kemampuan partikel karet dalam proses pembuatan kompon dapat dilihat dari nilai Viskositas Mooney karakteristik karet alam (Zheleva, 2013). Hasil pengujian viscositas Mooney disajikan pada Gambar 5.

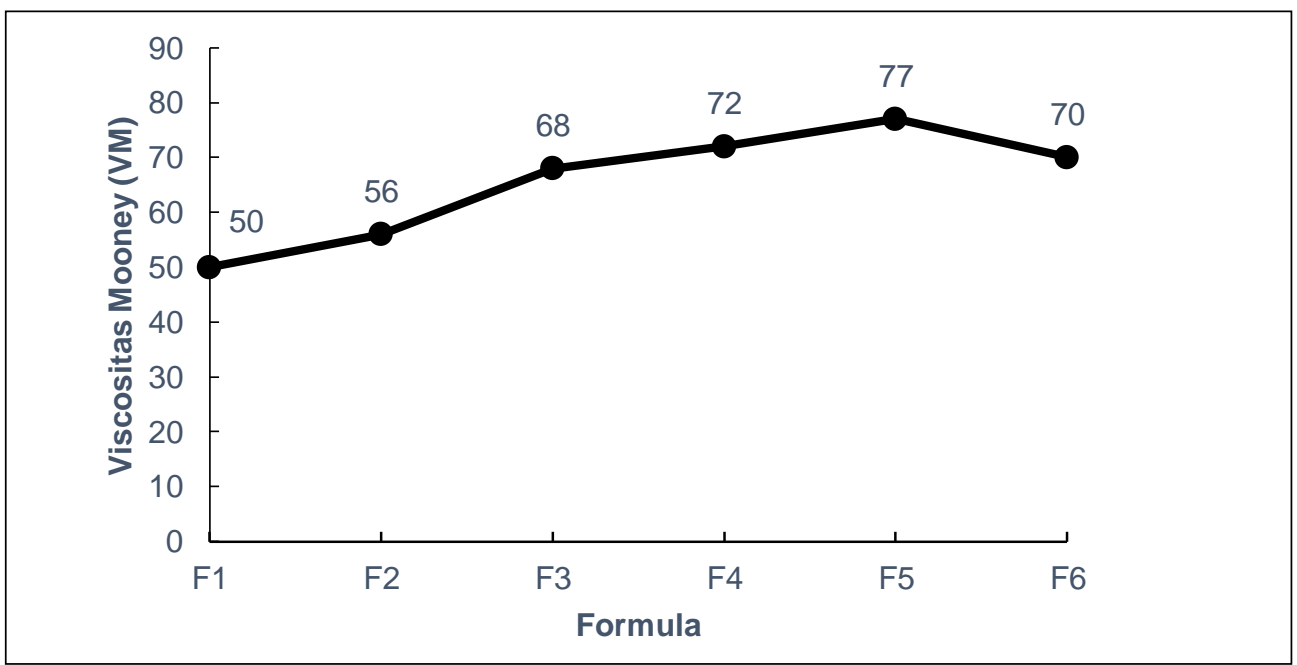

Gambar 5. Viskositas Mooney Karet Lembaran

Hasil pengujian viskositas Mooney menunjukkan perlakuan F1 terendah, yaitu 50 dan tertinggi perlakuan F5, yaitu 77 . Hal ini menunjukkan bahwa kemampuan gugus $\mathrm{OH}$ pada permukaan arang aktif bambu berinteraksi dengan molekul karet menghasilkan viskositas yang lebih tinggi. Arang yang ditambahkan dalam proses penggumpalan lateks, menyebabkan karet memiliki ketahanan terhadap gesekan. Peningkatan nilai viskositas mooney karet lembaran dipengaruhi banyaknya reaksi ikatan yang terjadi dengan meningkatnya rapat ikatan silang rantai molekul karet. (Refrizon, 2003; Liu and Hui, 2019).

Semua perlakuan berdasarkan Gambar 5, menunjukkan nilai viskositas Mooney karet lembaran antara 50 hingga 77 . Viskositas mooney pada standar mutu SIR, SNI 06-1903-2000 tidak dipersyaratkan (Tabel 1). Nilai viskositas Mooney komersial yang ditetapkan pada pabrik-pabrik SIR adalah minimal 40 sehingga nilai viskositas Mooney karet lembaran untuk semua perlakuan memenuhi standar mutu viskositas Mooney komersial. 


\section{SIMPULAN}

Arang aktif bambu sebagai bahan pengisi pada proses pengolahan lateks pekat mempengaruhi karakteristik karet lembaran, meliputi kadar abu, indeks ketahanan plastisitas (PRI), plastisitas awal (Po), dan viskositas Mooney. Kadar abu untuk semua perlakuan dengan kisaran nilai $0,58 \%-0,75 \%$, memenuhi standar kualitas SIR sesuai SNI 06-1903-2000, sedangkan untuk perlakuan F3 hingga F6 dengan nilai Po 34-40 dan PRI dengan nilai 52-72.

\section{DAFTAR PUSTAKA}

1. Ahmadi, S. S., A. Cifriadi, dan Hidayah, M.H. 2015. Redistilat Asap Cair dari Cangkang Kelapa Sawit dan Aplikasinya sebagai Koagulan Lateks. J. Penelitian Karet. 33 (2): 183-192.

2. Aguele, F. A., Idiaghe, J. A., dan Apugo-Nwosu, T. U. 2015. A Study of Quality Improvement of Natural Rubber Products by Drying Methods. J. Materials Sci. Chem. Eng. 3 (11): 712.

3. Asni, N. dan Novalinda, D. 2012. Improvement of Rubber Product Quality and Elimination of Smell Through the Use of Deorub Liquid Smoke as Latex Coagulant. Prosiding Seminar Nasional Sains dan Inovasi Teknologi Pertanian. p. 99-108.

4. BSN. 2000. Standard Indonesian Rubber. SNI 06.1903-2000, Badan Standardisasi Nasional. Jakarta.

5. Cao, Q., Xie, K. C., Lu, Y. K., dan Bao, W. R. 2011. Process Effect an Activated Carbon with Spesific Surface Area from Corn Cob. China: Key Laboratory for Coal Science and Technology of Shanxi Province and Ministry of Education Taiyuan University of Technology. p. 110-115.

6. Daud, W. M. A., dan Ali, W. S. W. 2004. Comparison of Pore Development of Activated Carbon Produced from Palm Shell and Coconut Shell. Bioresource Tech. 93: 63-69.

7. Egwaikhide, A. P, Okieimen, F. E, and Lawal. U. 2013. Rheological and Mechanical Properties of Natural Rubber Compounds Filled with Carbonized Palm Kernel Husk and
Viskositas Mooney karet lembaran semua perlakuan berkisar antara 50 hingga 77 , sesuai dengan standar mutu viskositas mooney SIR komersial.

\section{UCAPAN TERIMA KASIH}

Terima kasih Penulis ucapkan kepada Bapak Budi Wijaya (PT. Felda Indo Rubber) yang telah memberikan bantuan pengadaan lateks dan informasi teknis sehingga penelitian ini dapat terlaksana.
Carbon Black (N330). Sci. J. Chem. 1 (5): 0-55

8. George, P. J. dan Jacob, C. K. 2010. Natural Rubber: Agromanagement and Cropprocessing. India: Rubber Research Institute of India. p.249-254.

9. Handayani, H. 2014. Pengaruh Berbagai Jenis Penggumpal Padat Terhadap Mutu Koagulum dan Vulkanisat Karet Alam. J. Penelitian Karet, 32: 74-80.

10. Intapun, J., Saint-Beuve, J., Bonfils, F., Tanrattanakul, V., Dubreuqe, E., dan Vaysse, L. 2009. Characteristics of Natural Rubber Cup Coagula Maturation Conditions and Consequences on Dry Rubber Properties. J. Rubber Res., 12 (4): 171-184.

11. Komethi, M., Othman, N., Ismail, dan Sasidharan, S. 2012. Comparative Study on Natural Antioxidant as an Aging Retardant for Natural Rubber Vulcanizates. J. Applied Polymer Sci. 124: 14901-500.

12. Krisdianto, G. Sumarni, dan A. Ismanto. 2000. Sari Hasil Penelitian Bambu. Departemen Kehutanan. Jakarta.

13. Liu, Q., dan Hui, L. 2019. Influence of Processing Technology on Mooney Viscosity and Burning Time of Mixed Rubber. Res. Appl. of Mater. Sci. 1(1): 24-27.

14. Malac, J. 2009. Viscosity, Relaxation and Stability of Natural Rubber. The Open Macromolecules J. p.41-44.

15. Marlina, P dan Prasetya, H.A. 2017. Karakteristik Karet lembaran dengan Bahan Baku Komposit Modifikasi Pati - 
Lateks. J. Dinamika Penelitian Industri. 28 (2): 112-119.

16. Marlina, P., Sugiyono, B., dan Prasetya, H.A. 2018. Ketahanan Usang Karet Peredam Goncangan Kendaraan Bermotor Roda Empat dengan Bahan Pengisi Arang Aktif Bambu. Prosiding Seminar Nasional Kulit, Karet, dan Plastik ke-7 Yogyakarta, 29 Agustus 2018. pp. 128 - 137

17. Muis, Y. 2010. Pengaruh Penggumpal Asam Asetat, Asam Formiat, dan Berat Arang Tempurung Kelapa Terhadap Mutu Karet. Sains Kimia, 11 (1): 21-24.

18. Refrizon/ 2003. Viskositas Mooney Karet Alam. Jurusan Fisika Fakultas Matematika dan IImu Pengetahuan Alam. Universitas Sumatera Utara. Medan.

19. Rijali, A., Usman, M., dan Zulkarnain. 2015. Pembuatan dan Karakterisasi Karbon Aktif dari Bambu Betung dengan Aktivasi Menggunakan Activating Agent $\mathrm{H}_{2} \mathrm{O}$. Jurnal FMIPA, 2(1): 102-107.
20. Roslan, S. A. H., Rasid, Z. A., dan Hassan, M. Z. 2015. The Natural Fiber Composites Based on Bamboo Fibers: A Review. J. Eng. Appl. Sci., 10(15): 6279-6288.

21. Sirait, M. 2011. Pengaruh Campuran Sari Jeruk Nipis dan Asam Format sebagai Bahan Penggumpal Lateks terhadap Sifat Vulkanisasi Karet. J. Penelitian Saintika, 11(1): 36 - 44.

22. Vachlepi, A. dan Suwardin, D. 2015. Karakteristik Mutu Karet Alam SIR 20CV Menggunakan Bahan Pemantap Hidrazine pada Suhu Penyimpanan $60^{\circ} \mathrm{C}$. J. Dinamika Penelitian Industri. 26(2): 85-93.

23. Zheleva, D. 2013. An Attempt for Correlation Between Mooney Viscosity and Rheological Properties of Filled Rubber Compounds. J. Chem. Technol. Mettalurgy. 38(3): 241-246.

24. Zhong, J. P., Cheng-Peng, L., SiDong, L., LingXue, K., Lei, Y., ShuangQuan, L., dan XiaoDong, S. 2009. Study on The Properties of Natural Rubber During Maturation. J. Polymr. Mater. 26(3): 351-36. 